\title{
Limitations to Postfire Seedling Establishment: The Role of Seeding Technology, Water Availability, and Invasive Plant Abundance
}

\author{
Jeremy J. James ${ }^{1}$ and Tony Svejcar ${ }^{2}$ \\ Authors are ${ }^{1}$ Plant Physiologist and ${ }^{2}$ Research Leader, US Department of Agriculture-Agricultural Research Service, \\ Eastern Oregon Agricultural Research Center, 67826-A Hwy 205, Burns, OR 97720, USA.
}

\begin{abstract}
Seeding rangeland following wildfire is a central tool managers use to stabilize soils and inhibit the spread of invasive plants. Rates of successful seeding on arid rangeland, however, are low. The objective of this study was to determine the degree to which water availability, invasive plant abundance, and seeding technology influence postfire seedling establishment. Across four fire complexes, whole plots were either seeded using a rangeland drill, seeded by hand where seeds could be placed at an exact depth, or left as unseeded controls. Irrigation and weeding treatments were applied to subplots within whole plots in an incomplete factorial design. In three of the four fires, seeding method was the single factor limiting establishment with seedling density over sevenfold higher in the hand-seeded compared to the drill-seeded treatments. In contrast to our hypotheses, water and weeding had no positive effect on seedling establishment in any of the four fires; however, background weed density was relatively low. The native community recovered at all sites with minimal bunchgrass mortality. These results strongly suggest a need for a decision framework that evaluates postfire seeding needs relative to natural recovery. Based on these initial results, it appears modest improvements in seeding technology may yield substantial increases in seeding success.
\end{abstract}

\section{Resumen}

La siembra en pastizales después de haberse dado una quema no controlada es una herramienta central que los manejadores usan para estabilizar el suelo e inhibir la expansión de plantas invasivas. Sin embargo, las tasas de siembras exitosas en pastizales áridos, son bajas. El objetivo de este estudio fue determinar el grado al cual la disponibilidad de agua, abundancia de plantas invasoras y la tecnología de siembra influencian el establecimiento de plántulas después de la ocurrencia del fuego. A través de cuatro complejos de incendios, se sembraron parcelas enteras, ya sea usando una sembradora de pastos o sembradas a mano donde las semillas podrían ser colocadas a una profundidad exacta o utilizar controles sin siembra. Tratamientos de riego y escarda fueron aplicados a sub-parcelas dentro de las parcelas en un diseño factorial, en tres de los cuatro incendios, el método de siembra fue el único factor que limitó el establecimiento, con una densidad de siembra de 7 veces mayor en parcelas sembradas a mano comparadas con las sembradas con la sembradora de pastos. En contraste con nuestras hipótesis, agua y escarda no tuvieron un efecto positivo en el establecimiento de plántulas en ninguno de los cuatro incendios; sin embargo, la densidad de las malezas fue relativamente baja. La comunidad nativa recubrió todos los sitios con una mínima mortalidad de pastos amacollados. Estos resultados sugieren fuertemente la necesidad por un marco de decisión que evalúe las necesidades del establecimiento de siembras después de la ocurrencia de incendios relativas a la recuperación natural. Basado en estos resultados iniciales, parece que modestas mejoras en la tecnología de siembra pueden producir un aumento substancial en el éxito de siembra.

Key Words: cheatgrass, disturbance, fire, restoration, revegetation, seed drill

\section{INTRODUCTION}

Seeding rangeland following wildfire is a central tool managers use to stabilize soils, inhibit the spread of invasive plants, and facilitate recovery of desirable vegetation (Brown and Amacher 1999). Much research has been directed toward examining methods to improve seeding success, and significant advancements in seeding technology and plant material have been made (e.g., Monsen and Stevens 2004; Jones and Monaco 2007). Despite these efforts, rates of successful seedings on arid

\footnotetext{
Correspondence: Jeremy J. James, US Department of Agriculture-Agricultural Research Service, Eastern Oregon Agricultural Research Center, 67826-A Hwy 205, Burns, OR 97720, USA. Email: jeremy.james@oregonstate.edu

Manuscript received 18 September 2009; manuscript accepted 19 February 2010.
}

rangeland are low and typically confined to years with above average crop year or growing season precipitation.

Although many factors affect seedling establishment (e.g., aspect, soil physical and chemical characteristics, seeding rate, plant material), it is likely that several key factors may have an overriding influence on postfire seedling establishment on arid rangeland. Given the water-limited nature of these systems it is not surprising that water availability has been commonly invoked as a key factor (e.g., Abbott and Roundy 2003; Jessop and Anderson 2007). Seeding failures also have been attributed to competition from invasive plant species (Cook 1965; Eiswerth et al. 2009). In addition, seeding failures also may be due to the inability of equipment to plant seeds at appropriate depths (Cox and Martin 1984; Young et al. 1994). However, the degree to which seeding failures can be attributed to inappropriate seed placement is generally unknown. 
Table 1. Site data, seeding data, and postfire native plant community response for the four fire complexes. Data are mean \pm SE. Species names and codes follow the USDA PLANTS database at http://plants.usda.gov/ (PSSP indicates Pseudoroegneria spicata; AGDE, Agropyron desertorum; AGSM, Agropyron smithii; LECI, Leymus cinereus; ELWA, Elymus wawawaiensis; POSE, Poa secunda; AGFR, Agropyron fragile; ACMI, Achillea millefolium; and LIPE, Linum perenne).

\begin{tabular}{|c|c|c|c|c|}
\hline & \multicolumn{4}{|c|}{ Fire complex } \\
\hline & Butte & Bartlett & Egley & Roundtop \\
\hline \multicolumn{5}{|l|}{ Site data } \\
\hline \multirow[t]{2}{*}{ Location } & long $43^{\circ} 27.583^{\prime} \mathrm{N}$ & long $43^{\circ} 43.601^{\prime} \mathrm{N}$ & long $43^{\circ} 33.494^{\prime} \mathrm{N}$ & long $43^{\circ} 32.166^{\prime} \mathrm{N}$ \\
\hline & lat $118^{\circ} 01.564^{\prime} \mathrm{W}$ & lat $118^{\circ} 22.068^{\prime} \mathrm{W}$ & lat $119^{\circ} 21.905^{\prime} \mathrm{W}$ & lat $119^{\circ} 54.494^{\prime} \mathrm{W}$ \\
\hline Soil texture (\% sand, silt, clay) & $25,61,14$ & $28,52,20$ & $36,53,11$ & $58,35,7$ \\
\hline Macrotopography variance $\left(\log \mathrm{cm}^{2}\right)$ & $1.63 \pm 0.05$ & $0.92 \pm 0.12$ & $0.99 \pm 0.02$ & $0.79 \pm 0.05$ \\
\hline Microtopography variance $\left(\log \mathrm{mm}^{2}\right)$ & $0.45 \pm 0.05$ & $0.15 \pm 0.05$ & $0.21 \pm 0.04$ & $0.26 \pm 0.06$ \\
\hline \multicolumn{5}{|l|}{ Seeding data } \\
\hline \multirow[t]{6}{*}{ Seed mix (species code, mix composition \%) } & (PSSP, 24) & (PSSP, 11) & (PSSP, 22) & (PSSP, 38) \\
\hline & (AGDE, 48) & (AGDE, 54) & (AGDE, 43) & (ELWA, 38) \\
\hline & (AGSM, 24) & $(\mathrm{LECl}, 11)$ & (AGFR, 22) & (POSE, 11) \\
\hline & (ACMI, 2) & $(\mathrm{ACMI}, 1)$ & $(\mathrm{LECl}, 11)$ & $(\mathrm{LECl}, 12)$ \\
\hline & (LIPE, 2) & (LIPE, 1) & (ACMI, 1) & (ACMI, 1) \\
\hline & & & $(\mathrm{LIPE}, 1)$ & \\
\hline Seeding rate $\left(\mathrm{kg} \cdot \mathrm{ha}^{-1}\right.$, seeds $\left.\cdot \mathrm{m}^{-2}\right)$ & $(9.01,429)$ & $(10.36,334)$ & $(10.36,370)$ & $(9.24,308)$ \\
\hline Planting date & 26 November 2007 & 28 November 2007 & 15 November 2007 & 2 November 2007 \\
\hline Field germination (\%) & $56.9 \pm 3.3$ & $67.1 \pm 2.5$ & $62.6 \pm 3.1$ & $78.4 \pm 2.1$ \\
\hline \multicolumn{5}{|l|}{ Postfire native community response } \\
\hline Soil N burned $\left(\mu \mathrm{g} \cdot \mathrm{cm}^{-2}\right)$ & $5.8 \pm 1.4$ & $4.6 \pm 0.4$ & $23.4 \pm 7.5$ & $10.7 \pm 2.3$ \\
\hline Soil $\mathrm{N}$ unburned $\left(\mu \mathrm{g} \cdot \mathrm{cm}^{-2}\right)$ & $2.02 \pm 0.2$ & $3.1 \pm 0.8$ & $2.4 \pm 0.4$ & $2.6 \pm 0.2$ \\
\hline Annual grass density (plants $\cdot \mathrm{m}^{-2}$ ) & $5.1 \pm 2.1$ & $8.5 \pm 2.7$ & $1.7 \pm 0.5$ & $2.3 \pm 0.3$ \\
\hline Bunchgrass density (plants $\cdot \mathrm{m}^{-2}$ ) & $1.5 \pm 0.6$ & $6.0 \pm 2.7$ & $2.9 \pm 0.4$ & $2.8 \pm 1.3$ \\
\hline Poa secunda density (plants $\cdot \mathrm{m}^{-2}$ ) & $12.7 \pm 0.1$ & $11.1 \pm 1.3$ & $16.1 \pm 0.9$ & $0.13 \pm 0.13$ \\
\hline Rhizomatous grass density (plants $\cdot \mathrm{m}^{-2}$ ) & 0 & 0 & 0 & $12.4 \pm 1.8$ \\
\hline Perennial forb density (plants $\cdot \mathrm{m}^{-2}$ ) & $28.5 \pm 6.8$ & $21.27 \pm 5.12$ & $7.8 \pm 4.4$ & $2.93 \pm 0.4$ \\
\hline Bunchgrass mortality $(\%)$ & $25.9 \pm 5.7$ & $1.7 \pm 1.2$ & $8.9 \pm 2.7$ & $7.0 \pm 2.6$ \\
\hline Native perennial plant standing crop $\left(\mathrm{kg} \cdot \mathrm{ha}^{-1}\right)$ & $374.6 \pm 69$ & $613.3 \pm 52.2$ & $790.7 \pm 102.2$ & $447.2 \pm 119.1$ \\
\hline
\end{tabular}

The objective of this study was to determine the degree to which water availability, invasive plant abundance, and seeding technology influence postfire seedling establishment. Across four fire complexes we applied watering and weeding treatments to plots that were either seeded using a rangeland drill or seeded by hand where exact depth of seed placement could be controlled. We hypothesized that watered, weeded, and hand-seeded plots would have higher seedling establishment than not watered, not weeded, and drill-seeded plots, respectively.

\section{METHODS}

In July and August 2007, four major fire complexes ignited in the Burns, Oregon, and Vale, Oregon, Bureau of Land Management districts. Fire locations, site characteristics, and seeding methods are described in Table 1. Functional group density, mortality of deep-rooted bunchgrasses, and perennial herbaceous standing crop was quantified in $750.25-\mathrm{m}^{2}$ quadrats distributed over five transects in June the second year following fire at each site. Soil nitrogen $(\mathrm{N})$ availability in burned and unburned portions of the plant community during the first growing season following fire was measured using ion exchange membranes buried in the upper $10 \mathrm{~cm}$ of the soil (Johnson et al. 2005). Unburned sites were located across fire breaks. Soil texture was analyzed using the hydrometer method following Bouyoucos (1962). Site microtopography was measured with a pin frame with pins spaced every $2.54 \mathrm{~cm}$ along a 1-m transect following Harper et al. (1965). In an analogous fashion, site macrotopography was measured along a $16-\mathrm{m}$ transect with pinpoints spaced $0.5 \mathrm{~m}$ apart. Transects were replicated 10 times. Heterogeneity is reported as the log variance in pin height across five replicate transects at each site (Harper et al. 1965). Soil compaction in drill- and hand-seeded plots was measured with a pocket penetrometer with 20 replicate measurements made per treatment per site (Bradford 1986). Field germination of seed mixes was quantified using a buried bag technique (Abbott and Roundy 2003).

Treatments were arranged in a split-plot design. At each fire, one 1-ha plot was split into three whole plots. Whole plots were randomly assigned to be either seeded with a rangeland drill, seeded by hand, or left as unseeded controls. Whole-plot seeding treatments were replicated once at each fire for a total 


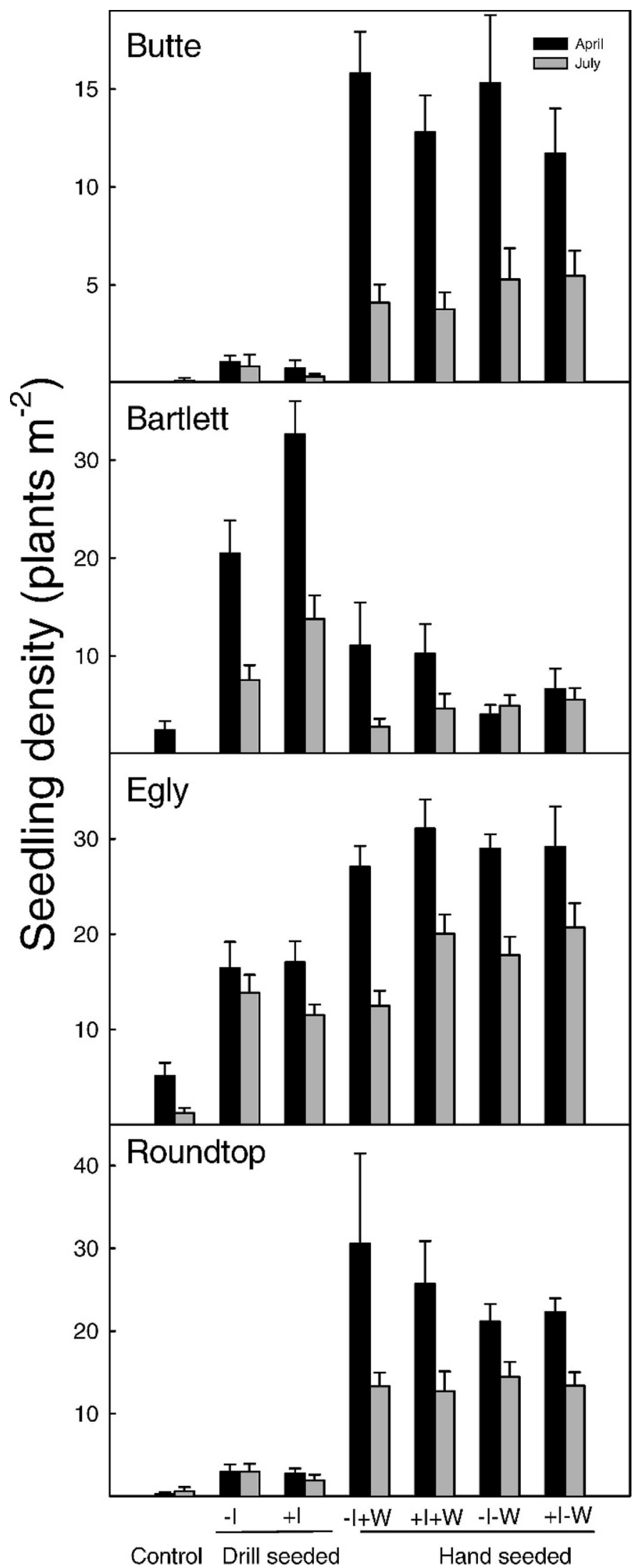

Figure 1. Density of seeded species within each of the four sites as affected by irrigation treatments that applied $20-\mathrm{mm}$ watering events every 2 wk in April and May $(+\mathrm{l})$ or plots that received no additional water $(-I)$, and treatments where plots were weeded weekly $(+W)$ or sample size of four. Irrigation and weeding treatments were randomly assigned in an incomplete factorial design to $2 \times 2 \mathrm{~m}$ subplots within each whole plot. Specifically, irrigation and weeding were not applied to unseeded control plots. Irrigation treatments but not weeding treatments were applied to drillseeded plots. Irrigation and weeding treatments were applied individually and in combination with the hand-seeded plots. Each subplot treatment was replicated eight times.

Drill seeding was done with a rangeland drill with regular furrow openers and 3.8-cm-depth bands. Drop tubes were pulled to allow smaller seeded species to fall on the soil surface. The hand-seeding treatment was done by making furrows by hand in the subplots similar in width and depth to the drill and then covering the seeds with $1 \mathrm{~cm}$ of soil followed by gentle compaction. Irrigation treatments consisted of applying approximately $20 \mathrm{~mm}$ of water every two weeks during April and May 2008. This additional water was equivalent to $70 \%$ of the long-term average growing season (March-May) precipitation. Weeded plots were weeded by hand.

Seeded species density was sampled in the four interior rows per subplot in April and July 2008, and final density and composition was sampled in July 2009. Because the native plant community largely recovered, inhibiting survival of seedlings (see Results), analysis of treatment effects was limited to the first growing season. A linear generalized mixed model was used to analyze density data because we were unable to normalize the data by transformation. Analysis was performed with the glimmix procedure in SAS (SAS Institute 2008). The irrigation and weeding treatments and sampling time were nested effects within seeding treatment. Random effects included fire complex and the interaction of fire complex with all other fixed factors. Estimate statements were used to compare treatments.

\section{RESULTS AND DISCUSSION}

Across the four fires seedling establishment values in the control, drill-seeded, and hand-seeded plots were 1.9 \pm 1.1 , $12.2 \pm 6.1$, and $18.4 \pm 4.6$ plants $\cdot \mathrm{m}^{-2}$, respectively. Seedling density was not significantly greater in the drill treatment compared to the control $(P=0.091)$, but the hand-seeding treatment significantly increased seedling density compared to the control $(P=0.043)$. Mean seedling density across all fires was approximately $50 \%$ higher in the hand-seeded compared to the drill-seeded plots. However, the Bartlett fire responded in the opposite direction compared to the other three fires with seedling densities in the hand-seeded treatment being lower than densities in the drilled treatment (Fig. 1). As a result, when all four fires were considered, seedling establishment in the hand-seeded plots was not significantly greater than seedling establishment in the drill-seeded plots $(P=0.351)$. The Bartlett site was the most clayey of the sites (Table 1), and soil

$\leftarrow$

where plots were left unweeded $(-W)$. Irrigation and weeding treatments were nested in an incomplete factorial design within the whole-plot treatments (control, drill-seeded, hand-seeded). Data are from April and June the first year following the fire (2008; mean $+\mathrm{SE}, n=8)$. 
compaction was significantly greater in the hand-seeded treatment compared to the drill-seeded treatment $(P<0.01$, $2.78 \pm 0.17$ and $1.11 \pm 0.13 \mathrm{~kg} \cdot \mathrm{cm}^{-2}$, mean $\left.\pm \mathrm{SE}, n=20\right)$. Significant differences in soil compaction between seeding treatments were not observed at the other sites (data not shown).

To evaluate the contribution of this site to the overall pattern of response we reran the original model without the Bartlett fire. In this scenario, seedling density was significantly greater in the hand-seeded treatment than the drill-seeded treatment $(P=0.024)$. The difference in establishment between hand- and drill-seeded was largest at the Butte and Roundtop fires (Fig. 1). The Roundtop fire was the sandiest site (Table 1) and experienced the most severe postfire wind erosion $(\mathrm{J}$. J. James, personal observation). Soils at the Butte fire, on the other hand, were relatively more stable but hummocks at the site caused pronounced variation in macrotopography ( $\mathrm{Ta}$ ble 1). Although these soil and landscape factors were not replicated across multiple sites, limiting inference, these results suggest the degree to which seeding technology limits establishment may, in part, be a predictable function of macrotopography and soil stability.

Contrary to our initial hypothesis and commonly expected limitations to seedling establishment, we found no evidence suggesting water availability in spring or invasive species abundance limited seedling establishment $(P>0.05$; Fig. 1). Nearby weather stations showed precipitation the year following the fire was close to or slightly below average. Although seedling densities declined through time, this appeared to primarily be a function of high native plant survival (Table 1). Averaged across fires in the drill-seeded treatments, $66 \%$ of the seed applied germinated, but only about $4 \%$ of this germinated seed emerged (Table 1; Fig. 1).

Weeding annual grasses had no detectable positive effect on seedling establishment at any of the sites (Fig. $1 ; P<0.05$ ), likely because of the low density of annual grasses following fire (Table 1). Although annual grasses were present at all sites before fire, and in some cases in very high densities (e.g., $>100$ plants $\cdot \mathrm{m}^{-2}$; James et al. 2008), annual grass abundance remained relatively low the first year following fire at all sites and played little role in determining initial seedling establishment. Cool spring temperatures following seeding $\left(4^{\circ} \mathrm{C}\right.$ below average at the Drewsey, Oregon, station) and moderately dry soils may have limited the ability of annual grasses to capitalize on soil resources immediately following the fire (Table 1). Alternatively, fire may have removed most of the annual grass seedbank. The low abundance of annual grasses following fire makes it difficult to evaluate the degree to which water availability and annual grass abundance interact to influence seedling establishment.

While fire at each site removed the sagebrush portion of the plant community, the native perennial herbaceous component recovered (Table 1). Low mortality of bunchgrasses and high postfire perennial plant density and standing crop indicate it was likely unnecessary to seed these sites. Evidence has periodically emerged questioning the need for postfire seeding (Ratzlaff and Anderson 1995; Pyke et al. 2003). In support of these observations, this study underscores a critical need to develop and apply effective decision criteria to determine the necessity of postfire seeding.

\section{MANAGEMENT IMPLICATIONS}

Seeding is a central component of emergency stabilization and burned area rehabilitation strategies for rangeland following wildfire, but probability of successful seeding is low. This study identifies three management implications for improving postfire reseeding efforts: 1) native perennial herbaceous species recovered well in all four fire complexes, indicating a need to formally develop and implement decision criteria to prioritize postfire seeding needs. 2) This study provides one of the first lines of evidence suggesting seeding technology as a central limitation to postfire seedling establishment. This limitation appears to be most pronounced on sites with substantial macrotopography or easily eroded soil surfaces where seedling establishment can be over sevenfold higher if appropriate planting depths are achieved. 3) This study illustrates a potentially smaller role for springtime precipitation in limiting seedling establishment than has been commonly assumed. Watering plots heavily in April and May did not increase establishment or survival. The fact that most of the seed across the four fires germinated but only $4 \%$ emerged points to processes such as mortality of germinated seed due to winter drought, freezing temperatures, or pathogens as potentially overriding factors in recruitment. Taken together these findings outline key opportunities to improve our understanding and ability to manage arid range systems following fire.

\section{LITERATURE CITED}

AвBоtт, L. B., ANd B. A. Roundy. 2003. Available water influences field germination and recruitment of seeded grasses. Journal of Range Management 56:56-64.

Bouyoucos, G. J. 1962. Hydrometer method improved for making particle size analysis of soils. Agronomy Journal 54:464-465.

Bradford, J. M. 1986. Penetrability. In: A. Klute [ED.]. Methods of soil analysis, part 1. Madison, WI, USA: American Society of Agronomy. p. 463-478.

Brown, R. W., and M. C. Amacher. 1999. Selecting plant species for ecological restoration: a perspective for land managers. In: L. K. Holzworth and R. W. Brown [EDS.]. Proceedings: Revegetation with native species. Ogden, UT, USA: US Department of Agriculture Forest Service, Rocky Mountain Research Station. p. 1-16.

Cook, C. W. 1965. Grass seedling response to halogeton competition. Journal of Range Management 18:317-321.

Cox, J. R., And M. H. Martin. 1984. Effects of planting depth and soil texture on the emergence of four lovegrasses. Journal of Range Management 37: 204-205.

Eiswerth, M. E., K. Krauter, S. R. Swanson, and M. Zielinski. 2009. Post-fire seeding on Wyoming big sagebrush ecological sites: regression analyses of seeded nonnative and native species densities. Journal of Environmental Management 90:1320-1325.

HarpeR, J. L., J. T. Williams, and G. R. Sagar. 1965. The behavior of seeds in soil I. The heterogeneity of soil surfaces and its role in determining the establishment of plants from seed. Journal of Ecology 53:273-286.

James, J. J., K. W. Davies, R. L. Sheley, and Z. T. Aanderud. 2008. Linking nitrogen partitioning and species abundance to invasion resistance in the Great Basin. Oecologia 156:637-648.

Jessop, B. D., And V. J. Anderson. 2007. Cheatgrass invasion in salt desert shrublands: benefits of postfire reclamation. Rangeland Ecology and Management 60:235-243.

Johnson, D. W., P. S. J. Verburg, and J. A. Arnone. 2005. Soil extraction, ion exchange resin, and ion exchange membrane measures of soil mineral 
nitrogen during incubation of a tallgrass prairie soil. Soil Science Society of America Journal 69:260-265.

Jones, T. A., AND T. A. Monaco. 2007. A restoration practitioner's guide to the restoration gene pool concept. Ecological Restoration 1:12-17.

Monsen, S. B., And R. Stevens [eds.]. 2004. Seedbed preparation and seeding practices. Fort Collins, CO, USA: US Department of Agriculture Forest Service Rocky Mountain Research Station. 698 p.

Pyke, D. A., T. 0. McArthur, K. S. Harrison, and M. Pellant. 2003. Coordinated intermountain restoration project-fire, decomposition and restoration. In: N. Allsopp and N. Walker [EDS.]. Proceedings of the VIlth International
Rangelands Congress; 28 July-1 August 2003; Durban, South Africa. Durban, South Africa: International Rangeland Congress. p. 1116-1124.

Ratzlaff, T. D., and J. E. Anderson. 1995. Vegetal recovery following wildfire in seeded and unseeded sagebrush steppe. Journal of Range Management 48:386-391.

SAS InSTITUTE. 2008. SAS/STAT User's Guide. Version 9.2. Cary, NC, USA: SAS Institute. $1028 \mathrm{p}$.

Young, J. A., R. R. Blank, W. S. Longland, and D. E. Palmouist. 1994. Seeding Indian ricegrass in an arid environment in the Great Basin. Journal of Range Management 47:2-7. 